\title{
Blockade of endogenous interleukin 12 results in suppression of murine streptococcal cell wall arthritis by enhancement of interleukin 10 and interleukin $1 \mathrm{Ra}$
}

Leo A B Joosten, Monique M A Helsen, Wim B van den Berg

\begin{abstract}
Objective-The goal of this study was to investigate the role of endogenous interleukin 12 (IL12) in acute murine streptococcal cell wall (SCW) arthritis.

Methods-C57black/6 mice were injected intraperitoneally with rat anti-murine IL12 (C17.8), shortly before induction of arthritis by intra-articular injection of 25 $\mu \mathrm{g} \mathrm{SCW}$ fragments into the right knee joint. Joint swelling and chondrocyte synthetic function was analysed several days after induction of SCW arthritis. Local cytokine profile was determined, protein by using ELISA and mRNA by RT-PCR technology. To confirm the findings at later time points, tissue chamber model of inflammation was used. Histology was performed to examine cell influx and cartilage damage.
\end{abstract}

Results-Suppression of joint swelling was noted at days 2 and 4, whereas no suppressive effect of anti-IL12 was found at day 1 . Severe inhibition of chondrocyte proteoglycan synthesis was seen at day 1 in both arthritic control and anti-IL12 treated mice. However, chondrocyte function was restored at day 4 of arthritis in the anti-IL12 injected animals, but not in the arthritic controls. Moreover, cell influx in synovial tissue and joint cavity was reduced by anti-IL12 treatment. Neutralisation of IL12 reduced the local levels of IL1ß, IL12 and interferon $\gamma$, when examined shortly after induction of SCW arthritis, whereas tumour necrosis factor $\alpha$ levels were not affected. In contrast, IL10 and IL1Ra protein and MRNA levels were strongly up regulated in synovial tissues after IL12 blockade. Enhancement of IL10 and IL1Ra by anti-IL12 was confirmed in a tissue chamber model with SCW induced inflammation.

Conclusions-This study indicates that IL12 is a pro-inflammatory cytokine during onset of acute SCW arthritis. Balances of proinflammatory and antiinflammatory cytokines were strongly improved by anti-IL12 treatment.

(Ann Rheum Dis 2000;59:196-205)

Interleukin 12 (IL12), originally described as cytotoxic lymphocyte maturation factor and natural killer cell stimulatory factor is a $70 \mathrm{kDa}$ heterodimeric cytokine consisting of two sub- units of $35 \mathrm{kDa}$ and $40 \mathrm{kDa}$. It is produced by phagocytic cells, dendritic cells, B-lymphocytes and NK cells upon stimulation with lipopolysaccharide (LPS), bacteria, and parasites. ${ }^{1-4}$ IL12 generates the development of naive $T$ cells into Th1 cells and stimulates interferon $\gamma$ (IFN $\gamma$ ) secretion by differentiated Th1 cells. ${ }^{56}$ Through major induction of IFN $\gamma$ and tumour necrosis factor $\alpha(\mathrm{TNF} \alpha)$, IL12 plays a crucial part in LPS lethal shock and generalised Schwartzman reaction. ${ }^{78}$ During bacterial infections, IL12 is considered to be a principal protective cytokine, where it bridges innate resistance and antigen specific immunity. ${ }^{9}$ Recently, it was demonstrated that IL12 deficient mice are unable to control bacterial infections with Leishmania major and were defective in IFN $\gamma$ production and Th1 responses. ${ }^{1011}$ In contrast, IL12 may unmask Th1 dependent autoimmune responses and may be a crucial intermediate in the often suggested link between bacterial infections and expression of autoimmune diseases. ${ }^{12}$ For instance arthritis has been associated with bacterial infections of the throat (rheumatic fever), the gastrointestinal tract (reactive arthritis), inflammatory bowel disease like Crohn's disease, and Lyme disease. In all of these cases IL12, induced by the bacterial organisms, may be the pivotal cytokine involved in the onset of arthritis. Rheumatoid arthritis (RA) is associated with Th1 immune response, however typical Th1 cytokines, like IL2, IFN $\gamma$ and TNF $\beta$ were hardly detected in synovial fluid or tissues. ${ }^{13}$ Recently, IL12 was detected in synovia of RA patients, and macrophage-like cells seems to be the main producers. ${ }^{14}$

Several bacterial arthritis models have been described and beside adjuvant arthritis (AA), induced by $M$ tuberculosis, streptococcal cell wall (SCW) arthritis is one of the important experimental animal models. Chronic arthritis can be induced in susceptible rat strains by an intraperitoneal injection of a sterile solution of bacterial cells or cell wall fragments from the group A streptococci. ${ }^{15}$ A reactivation model of local SCW arthritis, induced by intra-articular injection of SCW into a rat ankle joint, can be achieved by intravenous rechallenge with SCW fragments. ${ }^{16} \mathrm{SCW}$ arthritis can also be induced in mice after immunisation with SCW fragments in complete Freund's adjuvant. After intra-articular injection of SCW fragments into the knee joint a chronic erosive arthritis will occur. In contrast, one single injection of SCW fragments into a knee joint of a naive mouse
Accepted for publication 4 November 1999 
leads to an acute joint inflammation. ${ }^{17}$ It has been shown that TNF $\alpha$ and IL1 play different parts in the latter SCW arthritis model. While $\mathrm{TNF} \alpha$ mediates only joint swelling, IL 1 is crucial regarding cartilage destruction and inflammatory cell influx. ${ }^{18}$ Furthermore, it was demonstrated that endogenous IL10 controls the severity of SCW arthritis, because anti-IL10 treatment aggravated SCW arthritis. ${ }^{19}$ Later on, at days 4 and 7 macrophage-like cells were noted in the synovial tissue. The maximum influx of inflammatory cells was seen at days 2 and 4 after the induction of SCW arthritis. ${ }^{18}{ }^{19}$

In this study, we investigated whether IL12, produced by synovial macrophages after injection of bacterial cell wall fragments, is involved in the onset and severity of acute SCW arthri-
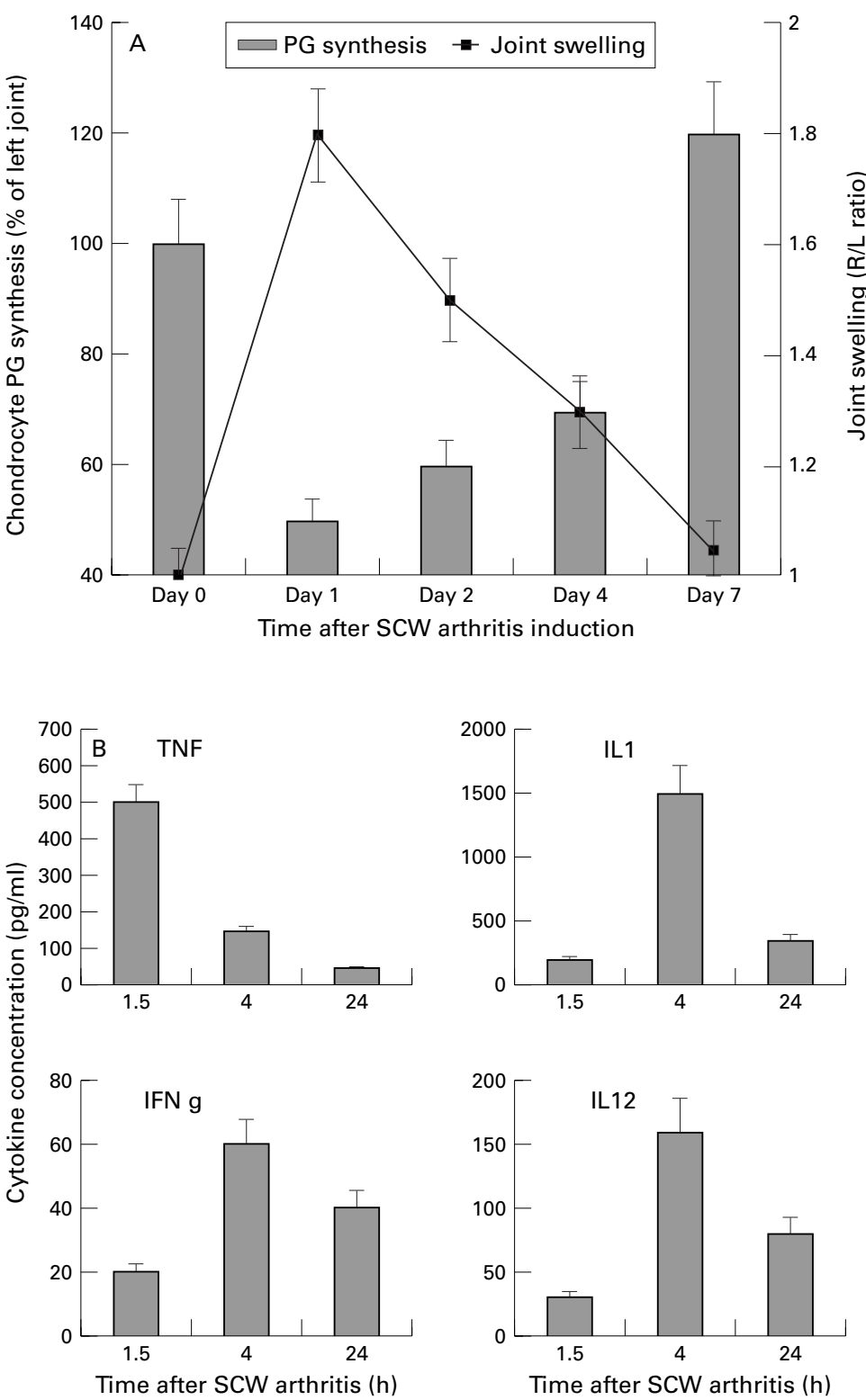

Figure 1 SCW arthritis, joint swelling, chondrocyte proteoglycan (PG) synthesis, and cytokine profile. (A) SCW arthritis was induced by injection of $25 \mu \mathrm{g} C \mathrm{SW}$ fragments. foint swelling was measured by ${ }^{99 m}$ Tc uptake method and is expressed as right/left ratio. A ratio $>1.10$ is considered as inflammation. Inhibition of chondrocyte PG synthesis was determined by ${ }^{35} S$-sulphate incorporation. The data represent the mean (SD) of at least seven mice per group. (B) Cytokine levels were determined either by RIA or ELISA in patellae washouts at several time points. The data represent the mean cytokine level of washouts of six patellae per time point. tis. Therefore we injected anti-murine IL12 antibodies before intra-articular application of SCW fragments. Joint swelling was monitored and joint pathology was examined by histology. Furthermore, local cytokine profile was determined by ELISA and RT-PCR technology. Because of the fact that synovial cytokine levels were only detectable in the first 24 hours of acute SCW arthritis, we further analysed the effect of endogenous IL12 blockade in a tissue chamber model of SCW inflammation. This study indicates that blockade of IL12 during onset of acute SCW arthritis suppresses secondary joint swelling, cell influx and restoration of chondrocyte PG synthesis by upregulation of IL10 and IL1Ra levels.

\section{Methods}

ANIMALS

Male C57/B16 mice were obtained at our university breeding facilities in Nijmegen. The mice were housed in filter top cages, and water and food were provided ad libitum. The mice were used at the age of 10-12 weeks.

\section{MATERIALS}

Ethidiumbromide, rat Igs, and bovine serum albumin were purchased from Sigma Chemicals, St Louis, USA. DNEM medium, RPMI 1640 medium, FCS, Taq DNA Polymerase, 100 bp DNA marker, TRIzol Reagent, and Agarose were obtained from Life Technologies, Breda, the Netherlands. GAPDH, IL1 $\beta$, IL10, IL12, IFN $\gamma$ and $\mathrm{TNF} \alpha$ primers were purchased from Eurogentec, Seraing, Belgium. Murine IL1Ra capture (MAP480) and detection (BAF480) antibodies and recombinant murine IL1Ra were obtained from R\&D Systems, Abingdon, UK. IL10 (CMC9102) and INF $\gamma$ (CMC4034) ELISA cytosets were obtained from Biosourche, Camarillo, CA, USA. Anti-mIL12 antibodies (capture 803891-01, detection 80-3892-01) were purchased from Genzyme, Cambridge, MA, USA. Murine IL12 was kindly provided by Dr S Wolf, Genetic Institute Inc, Cambridge, MA, USA.

ANTI-IL12 ANTIBODIES

Hybridoma cells producing rat anti-murine IL12 antibodies (C17.8) were kindly provided by G Trinchieri, Wistar Institute, Philidelphia, USA. Hybridoma cells $\left(3.10^{6}\right)$ were injected in nude $\mathrm{Balb} / \mathrm{C}$ mice and after three weeks ascites fluid was collected. Thereafter Igs were isolated using a protein-G column. Anti-murine IL12 antibodies $(0.5 \mathrm{mg})$ were injected in a volume of $0.2 \mathrm{ml}$ phosphate buffered saline (PBS).

SCW PREPARATION AND INDUCTION OF SCW ARTHRITIS

Streptococcus pyogenes T12 organisms were cultured overnight in Todd-Hewitt broth. Cell walls were prepared as described previously. ${ }^{17}$ The resulting $10000 \times g$ supernatant was used throughout the experiments. These preparations contained $11 \%$ muramic acid. Unilateral arthritis was induced by intra-articular injection of $25 \mu \mathrm{g} \mathrm{SCW}$ (rhamnose content) in $5 \mu \mathrm{l}$ 
PBS into the right knee joint of naive mice. As a control, PBS was injected into the left knee joint.

ANTI-IL12 TREATMENT

Two hours before induction of acute SCW arthritis, mice were given an intraperitoneal injection of $0.5 \mathrm{mg}$ purified rat anti-murine IL12. As previously described, this dose has been shown to be effective in vivo. ${ }^{70}$ As control the same amount of normal rat Igs was injected. For time course experiments, mice were injected intraperitoneally at -2 hours, day 1 and day 2 after the induction of acute SCW arthritis. To neutralise IL12 during SCW inflammation in the tissue chambers, mice were intraperitoneally injected with anti-IL12 two hours before injection of SCW fragments into the tissue chambers.

MEASUREMENT OF JOINT INFLAMMATION

SCW arthritis was quantified by the ${ }^{99 \mathrm{~m}} \mathrm{Tc}$ uptake method. ${ }^{21}$ This method measures by external gamma counting the accumulation of
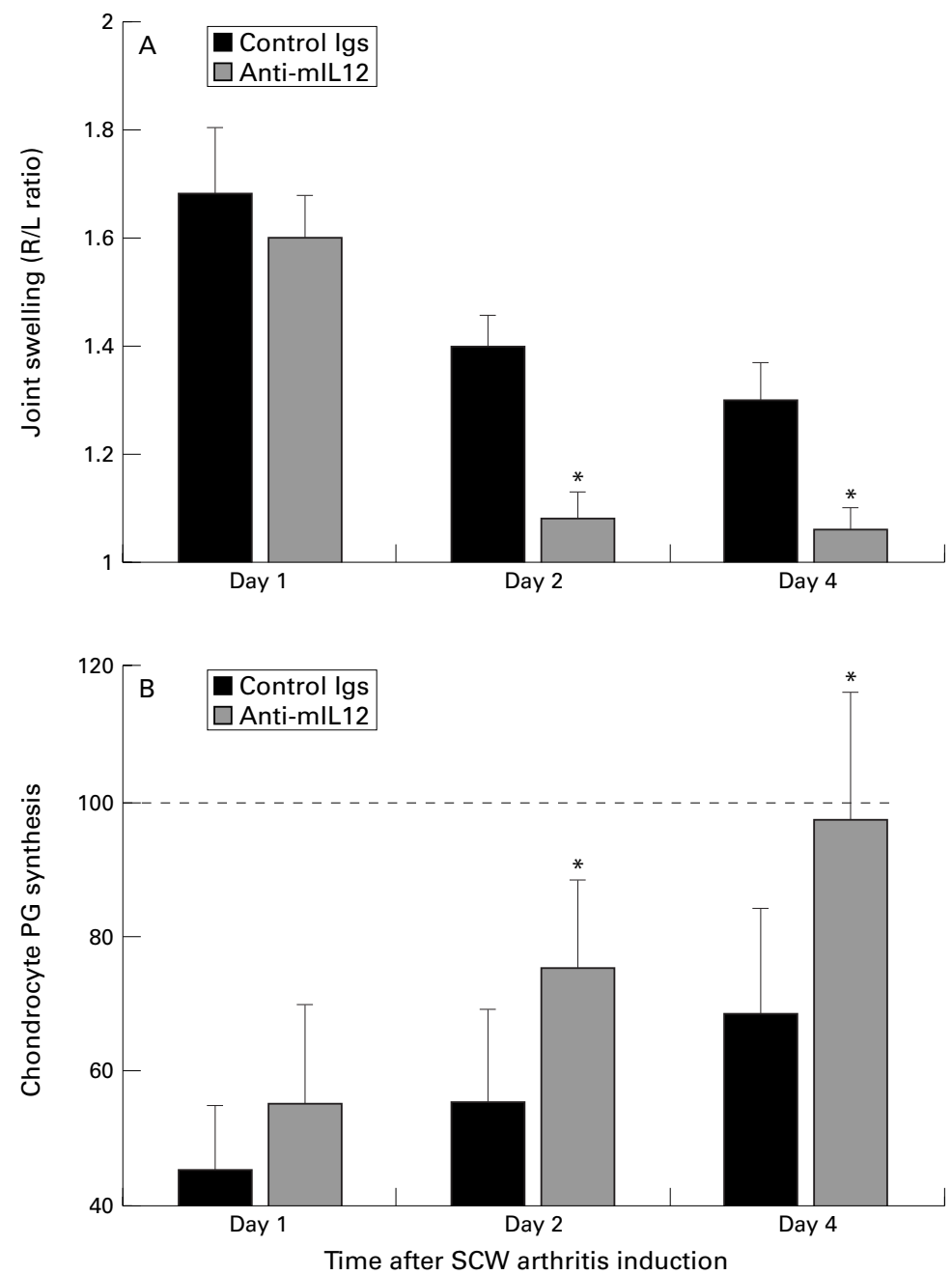

Figure 2 Effect of anti-IL12 treatment on joint swelling and chondrocyte PG synthesis. (A) Mice were given an intraperitoneal injection two hours before induction of arthritis with either $0.5 \mathrm{mg}$ rat anti-murine IL 12 or rat Igs. At days 1, 2, and 4 joint swelling was determined by ${ }^{99 m} T C$ uptake and expressed as R/L ratio. The data represent the mean (SD) of at least seven mice per group. (B) Chondrocyte PG synthesis was measured by

35S-sulphate incorporation at days 1,2, and 4 after induction of arthritis. The data represent mean (SD) percentage chondrocyte PG synthesis of the left control patella. ${ }^{*} p<0.05$, Mann-Whitney $U$ test, compared with rat Igs group. a small radioisotope at the site of inflammation attributable to local increased blood flow and tissue swelling. The severity of inflammation is expressed as the ratio of the ${ }^{99 \mathrm{~m}} \mathrm{Tc}$ uptake in the right (inflamed) over the left (control) knee joint. All values exceeding 1.10 were assigned as inflammation.

\section{CHONDROCYTE PROTEOGLYCAN SYNTHESIS}

DETERMINATION

Patellae with minimal surrounding tissue, were placed in RPMI 1640 medium with glutamax, gentmicin $(50 \mu \mathrm{g} / \mathrm{ml})$ and ${ }^{35} \mathrm{~S}$-sulphate $(0.74$ $\mathrm{MBq} / \mathrm{ml}$ ). After three hours of incubation at $37^{\circ} \mathrm{C}$ in a carbon dioxide incubator, patellae were washed in saline three times, fixed in $4 \%$ formaldehyde and subsequently decalcified in $5 \%$ formic acid for four hours. Patellae were punched out of the adjacent tissue, dissolved in $0.5 \mathrm{ml}$ Luma Solve at $65^{\circ} \mathrm{C}$ (Ominlabo) and after addition of $10 \mathrm{ml}$ Lipoluma (Omnilabo) the ${ }^{35} \mathrm{~S}$ content was measured by liquid scintillation counting. Values are presented as percentage ${ }^{35} \mathrm{~S}$ incorporation of the left control joint.

CYTOKINE PRODUCTION IN A MOUSE TISSUE CHAMBER MODEL OF INFLAMMATION Autoclaved sterile Teflon (Teflon-PFA, kind gift of Novartis, Basel, Switzerland) tissue chambers $(20 \mathrm{~mm} \times 8 \mathrm{~mm}$ diameter perforated by 135 regularly spaced $1 \mathrm{~mm}$ holes) were implanted subcutaneously under aseptic conditions through a small incision into the backs of mice. ${ }^{22}$ The incisions were closed by wound clips and the chambers were tested for sterility after seven days by culturing a $10 \mu \mathrm{l}$ sample on LB agar for 24 hours at $37^{\circ} \mathrm{C}$. Thereafter SCW inflammation was induced by injection of 100 $\mu \mathrm{SCW}$ fragments $(4 \mathrm{mg} / \mathrm{ml}$ rhamnose content). At days 1 and 2 after induction of inflammation samples of tissue chambers fluid $( \pm 200 \mu \mathrm{l})$ were taken. The samples were centrifuged for five minutes at $1000 \mathrm{~g}$ and stored at $-80^{\circ} \mathrm{C}$ until cytokine determination.

CYTOKINE MEASUREMENTS

To determine the levels of IL1 $\beta$, IL10, IL12, IFN $\gamma$ or $\mathrm{TNF} \alpha$ in patellae washouts, patellae were isolated from inflamed knee joints as previously described. ${ }^{18}{ }^{19}$ Patellae were cultured in RPMI 1640 medium (200 $\mu \mathrm{l} /$ patella) for one hour at room temperature. Thereafter, supernatant was harvested and centrifuged for five minutes at $1000 \mathrm{~g}$. IL $1 \beta$ and TNF $\alpha$ were determined by RIA. ${ }^{23}$ IL1Ra, IL10, IL12 and IFN $\gamma$ levels was measured by ELISA. The sensitivity of the ELISA for IL1Ra, IL10, IL12, IFN $\gamma$ and the RIA for IL $1 \beta$ and TNF $\alpha$ is 80 , 40, 2010,20 and $40 \mathrm{pg} / \mathrm{ml}$, respectively. The same assays were used for determination of cytokine levels in tissue chamber fluid samples

RNA ISOLATION

Mice were killed by cervical dislocation, immediately followed by dissection of the patella with adjacent synovium. ${ }^{24}{ }^{25}$ From six patella specimens synovium biopsy specimens were taken. Two biopsy specimens with a diameter of $3 \mathrm{~mm}$ were punched out, using a biopsy 

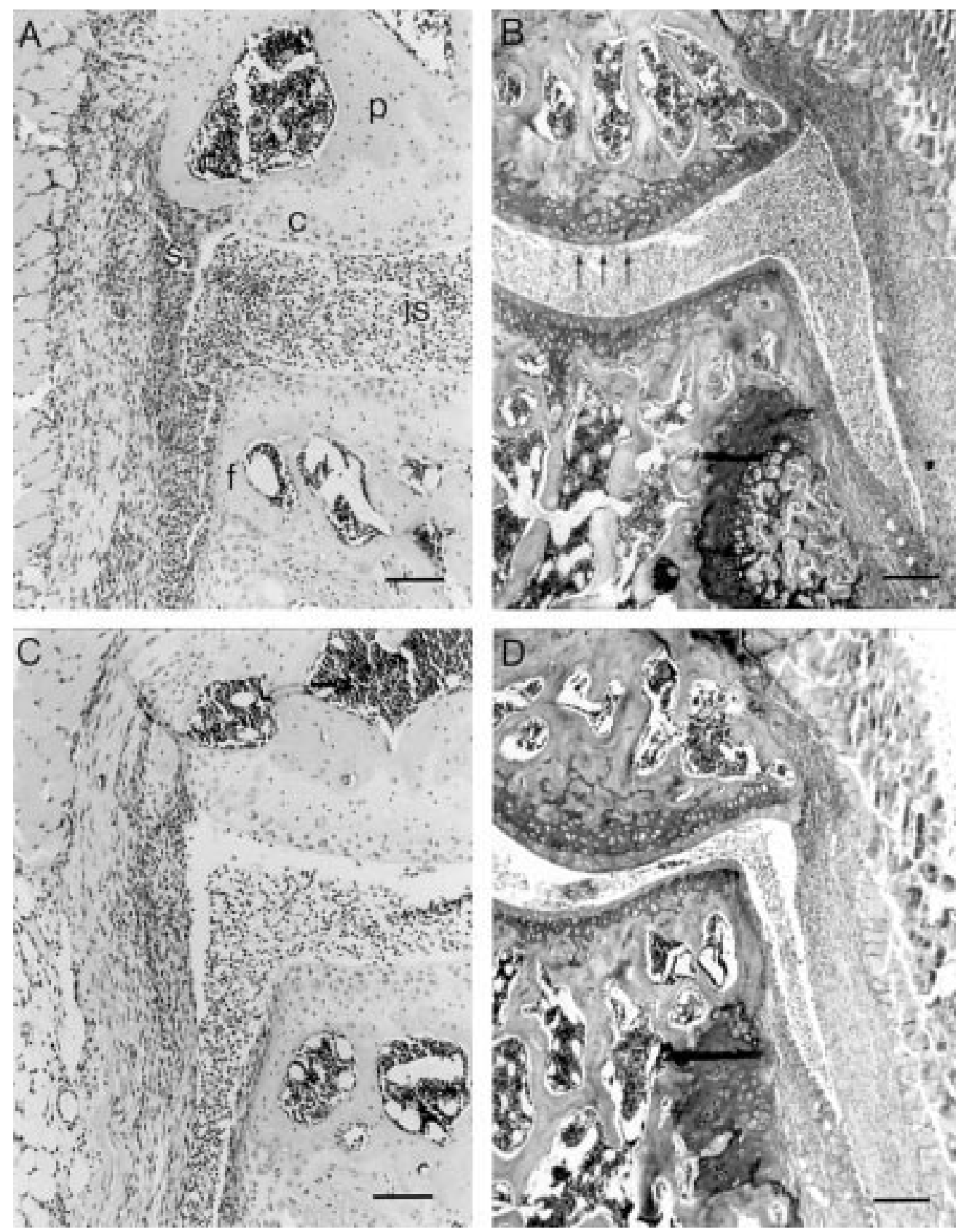

Figure 3 Effect of IL12 blockade on cell influx and cartilage damage in the knee joint. (A) Arthritic nee joint of the rat Igs treated control group. Note the marked joint inflammation and cell influx in the joint cavity. Bar $=80 \mu M$. (B) Section of the control group stained for matrix proteoglycan. Note the loss of matrix $P G$ in the cartilage layers (arrows). Bar $=40$ $\mu M$. (C) Knee joint of a mouse treated with anti-IL12 antibodies. Strong reduction of cell influx can be seen in synovial tissue and joint cavity. Bar $=80 \mu M$. (D) Section of anti-IL12 treated knee joint stained for PG loss. No reduction of matrix $P G$ depletion was seen after IL12 blockade. Bar $=40 \mu \mathrm{M}$. $p=$ patella, $f=$ femur, $c=$ cartilage, $j s=$ joint space, $s=$ synovium. ( $A$ and $C$ ) Haematoxilin and eosin staining, $(B$ and $D)$ safranin $O$ staining. All specimens were taken at day 2 after induction of $S C W$ arthritis.

Table 1 foint pathology after neutralisation of endogenous IL12

\begin{tabular}{lllll}
\hline $\begin{array}{l}\text { Days of } \\
\text { arthritis }\end{array}$ & Treatment & $\begin{array}{l}\text { Cell influx } \\
\text { synovial tissue }\end{array}$ & $\begin{array}{l}\text { Cell influx } \\
\text { joint cavity }\end{array}$ & $\begin{array}{l}\text { Matrix PG } \\
\text { depletion }\end{array}$ \\
\hline Day 2 & Control (Igs) & $0.8(0.2)$ & $1.8(0.4)$ & $1.0(0.2)$ \\
Day 2 & Anti-IL12 & $0.4(0.3)$ & $0.7(0.3)^{\star}$ & $0.9(0.3)$ \\
Day 4 & Control (Igs) & $1.3(0.3)$ & $1.9(0.4)$ & $1.7(0.4)$ \\
Day 4 & Anti-IL12 & $1.0(0.3)$ & $0.6(0.3)^{\star}$ & $1.2(0.3)$ \\
\hline
\end{tabular}

Mice were given an intraperitoneal injection injected with either rat Igs $(0.5 \mathrm{mg})$ or anti-IL12 (0.5 $\mathrm{mg}$ ) two hours before induction of an unilateral arthritis by intra-articular injection of $25 \mu \mathrm{g} \mathrm{SCW}$ fragments into the right knee joint. Histology was taken at days 2 and 4 of SCW arthritis and performed as described in Methods. Data represent the mean (SD) of two identical experiments, each experiment consisted of at least seven mice per group. ${ }^{\star} \mathrm{p}<0.05$, Mann-Whitney $U$ test compared with control. punch (Stiefel, Wachtersbach, Germany): one from the lateral and one from the medial side. Six patella specimens per experimental group were taken and three lateral and three medial biopsy specimens were pooled, to yield two samples per group. The synovium samples were immediately frozen into liquid nitrogen. Synovium biopsy specimens were ground to powder using a micro-dismembrator II (B Braun, Melsungen, Germany). Total RNA was extracted in $1 \mathrm{ml}$ TRIzol reagent, an improved single step RNA isolation method based on the 
method described by Chomczynski and Sacchi. ${ }^{26}$

PCR AMPLIFICATION

One microgram of synovial RNA was used for RT-PCR. Messenger RNA was reverse transcribed to cDNA using oligodT primers and $1 / 20$ of the cDNA was used in one PCR amplification. PCR was performed at a final concentration of $200 \mathrm{mM}$ dNTPs, $0.1 \mathrm{mM}$ of each primer, and 1 unit Taq-polymerase in standard PCR buffer. The mixture was overlaid with mineral oil and amplified in a thermocycler (Omnigene, Hybaid Ltd, UK). Message for GAPDH, IL1 $\beta$, IL10, IL12, IFN $\gamma$ and TNF $\alpha$ was amplified using the primers as previously described. ${ }^{27}$ Samples of $5 \mu \mathrm{l}$ were taken from
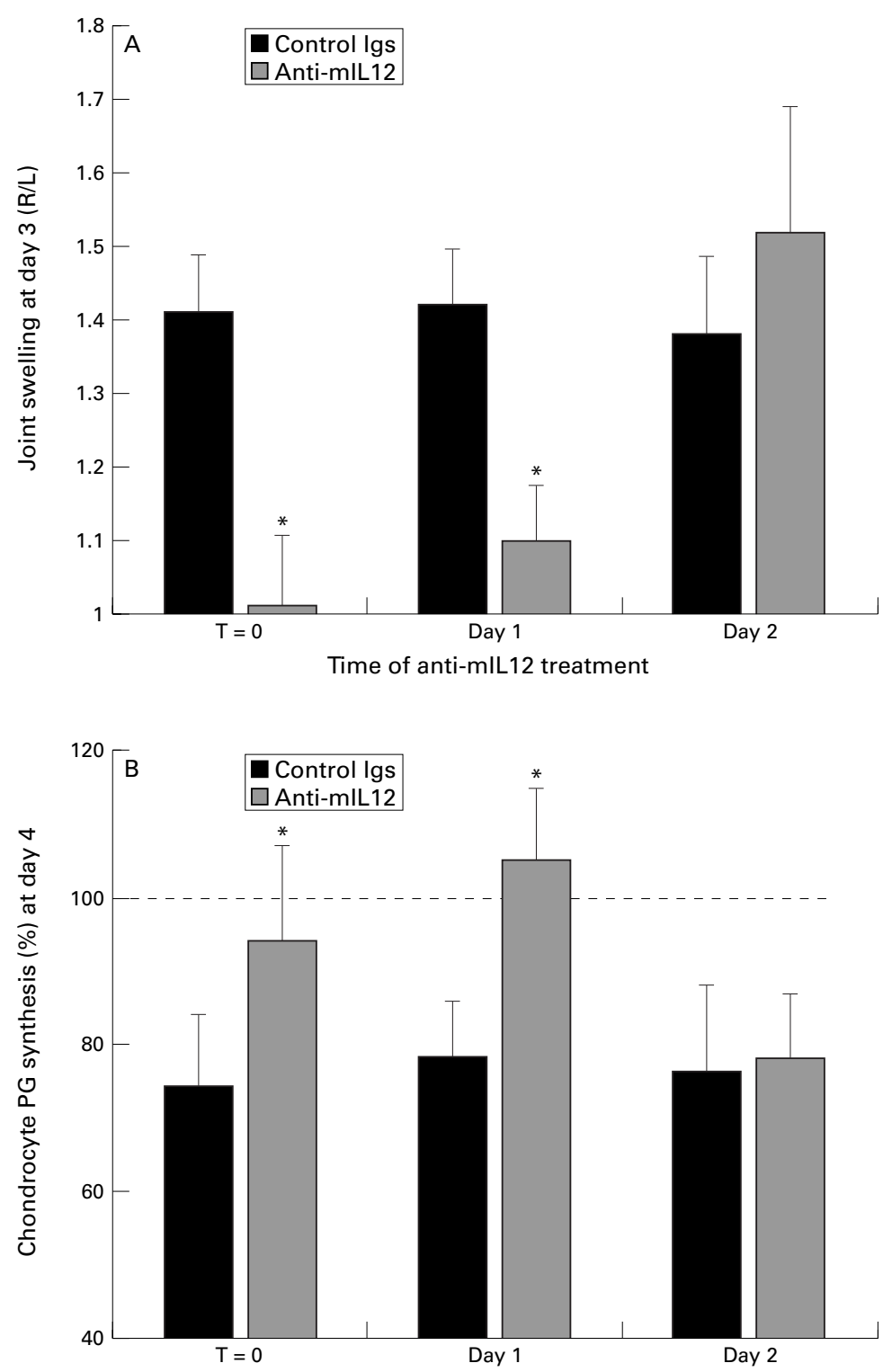

Time of anti-mIL12 treatment

Figure 4 Kinetics of IL12 neutralisation on joint swelling and chondrocyte PG synthesis. (A) Mice were treated intraperitoneally with anti-IL12 at either -2 hours, day 1 or day 2 after induction of SCW arthritis. As control we injected at the same time points rat Igs. foint swelling was determined at day 3. The data represent the mean (SD) joint swelling of at least seven mice per group. (B) Chondrocyte PG synthesis measured at day 4 . Mice were treated with either anti-IL12 or rat Igs as indicated above. The data are expressed as mean (SD) percentage of chondrocyte PG synthesis found in left control patella of at least seven patellae per group. ${ }^{*} p<0.05$, Mann-Whitney $U$ test, compared with rat Igs.
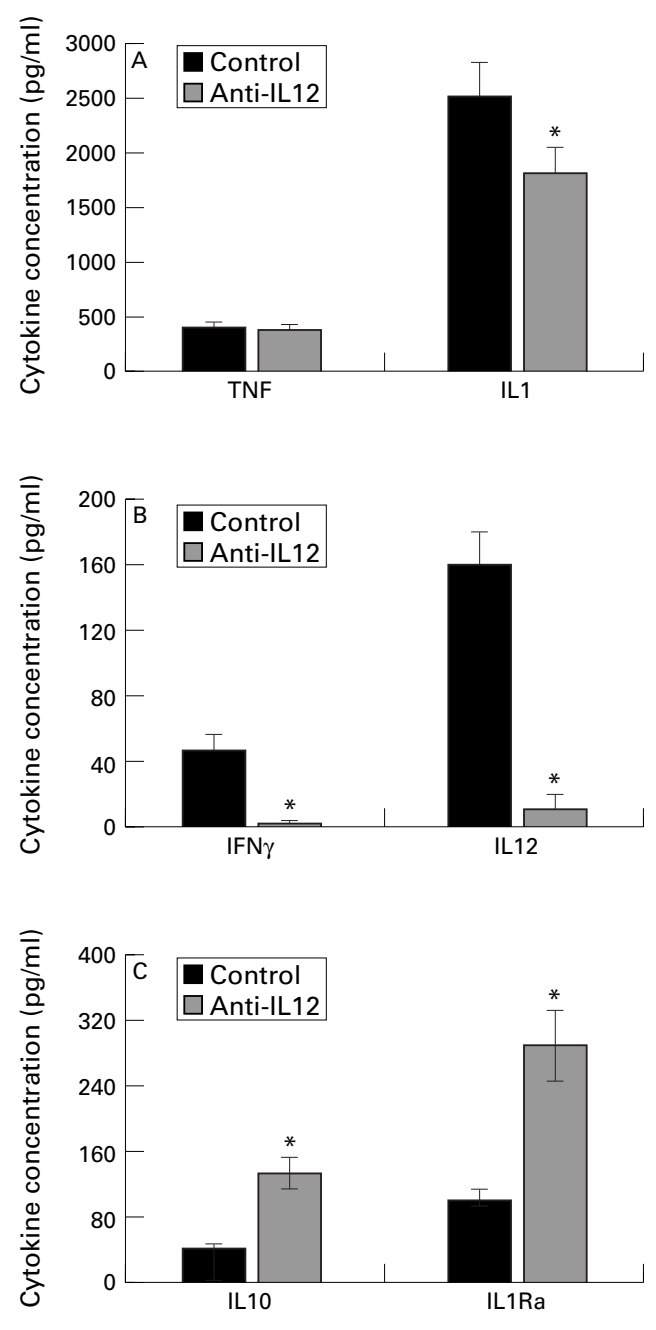

Figure 5 Synovial cytokine concentrations after IL12 neutralisation. Mice were given an intraperitoneal injection with either anti-IL12 or rat Igs before induction of arthritis. After either 90 minutes (TNFa) or four hours (all other cytokines), patellae were isolated and cytokine levels were determined in washouts. A, TNFa and IL1 $\beta$. (B) IFN $\gamma$ and IL12. C, IL10 and IL1Ra. The data represent mean (SD) cytokine level in at least six patellae washouts. ${ }^{\star} p<0.05$, Mann-Whitney $U$ test, compared with rat Igs group.

the reaction tubes after a certain number of cycles. The cycle curves were performed by two cycle intervals. PCR products were separated on $1.6 \%$ agarose and stained with ethidiumbromide. The results are presented as differences in PCR cycles between mRNA isolated from inflamed synovium compared with normal synovium. GAPDH levels were very consistent in all samples, not warranting any further correction of mRNA values for IL $1 \beta$, IL10, IL12, IFN $\gamma$ and TNF $\alpha$.

HISTOLOGICAL EXAMINATION

Mice were killed by ether anaesthesia. Thereafter, whole knee joints were removed and fixed for four days in $4 \%$ formaldehyde. After decalcification in $5 \%$ formic acid the specimens were processed for paraffin wax embedding. Tissue sections $(7 \mathrm{~mm})$ were stained with haematoxylin and eosin or safranin O. Histopathological changes were scored using the following parameters. Infiltration of cells was scored on a scale of $0-3$, depending on the amount of 
inflammatory cells in the synovial cavity and synovial tissues. Proteoglycan depletion was determined using safranin $\mathrm{O}$ staining. The loss of proteoglycans was scored on a scale of $0-3$, ranging from full stained cartilage to destained cartilage or complete loss of articular cartilage. Histopathological changes in the knee joints were scored in the patella/femur region on five semi-serial sections of the joint, spaced $70 \mathrm{mM}$ apart. Scoring was performed on decoded slides by two observers, as described earlier. $^{18} 192528$

STATISTICAL ANALYSIS

Differences between experimental groups were tested using the Mann-Whitney U test, unless stated otherwise.
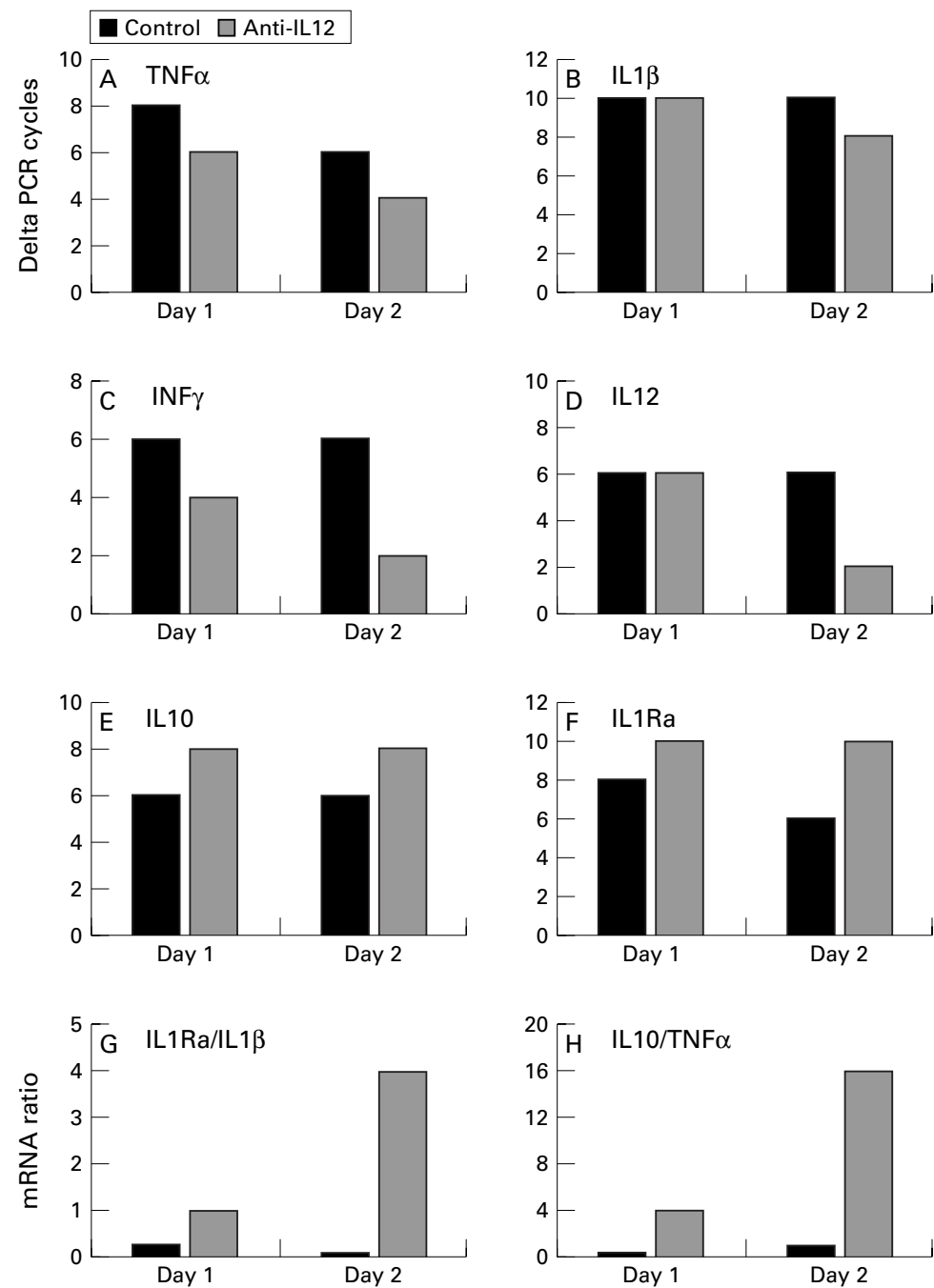

Figure 6 RT-PCR analysis of synovial tissue $m R N A$ levels for TNFa $(A), I L 1 \beta(B)$, IFN $(C), I L 12(D), I L 10(E)$, IL1Ra $(F)$ after intraperitoneal treatment with either IFN $(C), I L 12(D), I L 10(E), I L 1 R a(F)$ after intraperitoneal treatment with either
anti-IL12 or rat Igs. Synovium biopsy specimens of six mice per group were pooled and $R N A$ was extracted. Expressed is the number of PCR cycles in which gene product of interest was first detectable compared with normal synovium. Values are the mean of two experiments with SCW arthritis. The cycle curves were done by two cycle intervals. The PCR measurements of a particular cytokine was routinely repeated three times. The variations never exceeded more than two cycles. The absolute difference in mRNA levels were calculated using the difference in PCR cycles between arthritic synovium and non-inflamed synovium (two cycles mean $2^{2}$ more $m R N A$, four cycles $=2^{4}$ ). From these values ratios for IL1Ra/IL1 $(G)$ and IL10/TNFa $(H)$ were calculated, using delta PCR cycles found in $F / B$ and $E / A$.

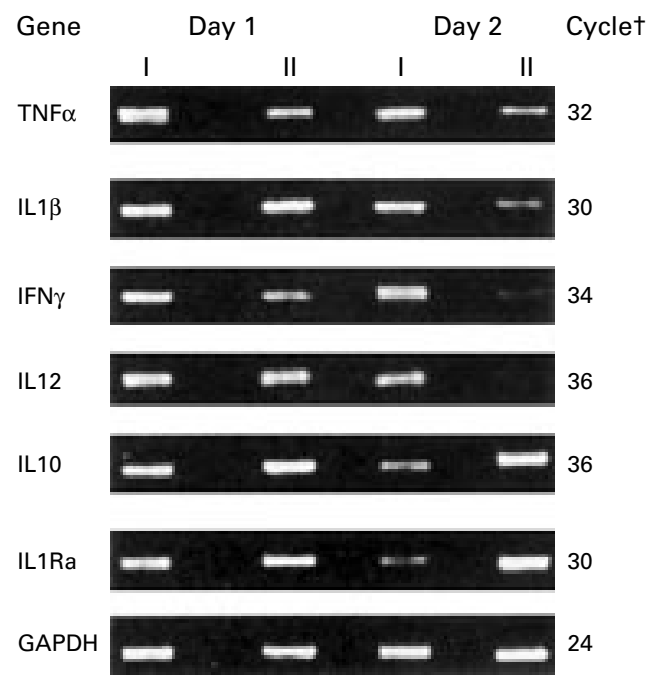

Figure $7 \quad P C R$ analysis of synovial tissue at days 1 and 2 after anti-IL12 treatment. Synovial biopsy specimens of six mice per experimental group were pooled, and RNA was extracted. PCR was performed as described in Methods. Animals were injected intraperitoneally with either $0.5 \mathrm{mg}$ rat Igs (I) or rat anti-murine IL12 (II) before induction of $S C W$ arthritis. Note the reduced IFN $\gamma$ and IL12 and the increased ILIRa and IL10 levels at day 2. + The number of PCR cycles.

\section{Results}

MURINE SCW INDUCED ARTHRITIS

One single injection of SCW fragments into a mouse knee joint leads to an acute inflammation, characterised by joint swelling and inhibition of chondrocyte proteoglycan (PG) synthesis in patellar cartilage. Significant knee joint swelling was found up to day 7 after injection of SCW fragments. Marked inhibition of chondrocyte PG synthesis was observed at days 1,2 and 4, whereas at day 7 an overshoot of chondrocyte PG synthesis was noted (fig 1A). To examine the cytokine pattern during the first stage of this type of experimental arthritis we analysed synovial tissue washouts (fig $1 \mathrm{~B}$ ). $\mathrm{TNF} \alpha$ and IL $1 \beta$ levels were increased shortly after injection of SCW fragments. At 90 minutes the highest levels (mean (SD) $450(40) \mathrm{pg} / \mathrm{ml}$ ) of TNF $\alpha$ were found, whereas the maximum IL1 $\beta$ levels were found at four hours (2520 (280) pg/ml). IL12 levels were detectable at $1.5,4,24$ and 48 hours after induction of arthritis, with the peak at four hours (160 (30) pg/ml). Protein levels of IFN $\gamma$ reached a maximum at four hours, 50 (15) $\mathrm{pg} / \mathrm{ml}$. As described previously, massive influx of polymorphonuclear cells (PMNs) in the joint cavity and synovial membrane was seen at days 1 and 2 .

REDUCTION OF SCW ARTHRITIS BY BLOCKING ENDOGENOUS IL12

To investigate the effect of neutralisation of endogenous IL12 on acute SCW arthritis, we gave an intraperitoneal injection of rat antimurine IL12 antibodies two hours before injection of SCW fragments. At day 1 no reduction of joint swelling was found. In contrast, marked suppression of joint swelling was seen at days 2 and 4 (fig 2A). Severe inhibition of chondrocyte PG synthesis was noted at day 1 in the arthritis control group treated with rat Igs. Blocking of IL12 had no 
significant effect on chondrocyte PG synthesis at day 1 . In line with the reduction of joint swelling at days 2 and 4, anti-IL12 treatment increased the chondrocyte PG synthesis (fig 2B). At day 4, the chondrocyte PG synthesis reached values found in normal cartilage (left joint), whereas in the arthritic control group (rat Igs) 30\% inhibition was seen. Histological examination showed that anti-IL12 treatment significantly reduced the number of inflammatory cells in the joint cavity at day 2 of SCW arthritis (fig 3A/C, table 1). Infiltration of synovial membrane with inflammatory cells was reduced by IL12 blocking although this did not differ significantly from the control group. No significant effect of anti-IL12 was seen on cartilage PG depletion as depicted in figure $3 \mathrm{~B} / \mathrm{D}$. Marked loss of $\mathrm{PG}$ was found in both control and anti-IL12 groups (table 1).

KINETICS OF ANTI-IL12 INDUCED SUPPRESSION OF SCW ARTHRITIS

To examine whether IL12 is only crucial at the onset of acute SCW arthritis or is involved as well at later stages of this type of joint inflammation we injected anti-IL12 at several time points. As shown above anti-IL12 treatment before induction of SCW arthritis suppressed both joint swelling and inhibition of chondrocyte PG synthesis (fig 4A/B). When anti-IL12 treatment was delayed until day 1 of arthritis we found nearly the same effects on

\section{- Control $\square$ Anti-IL12}
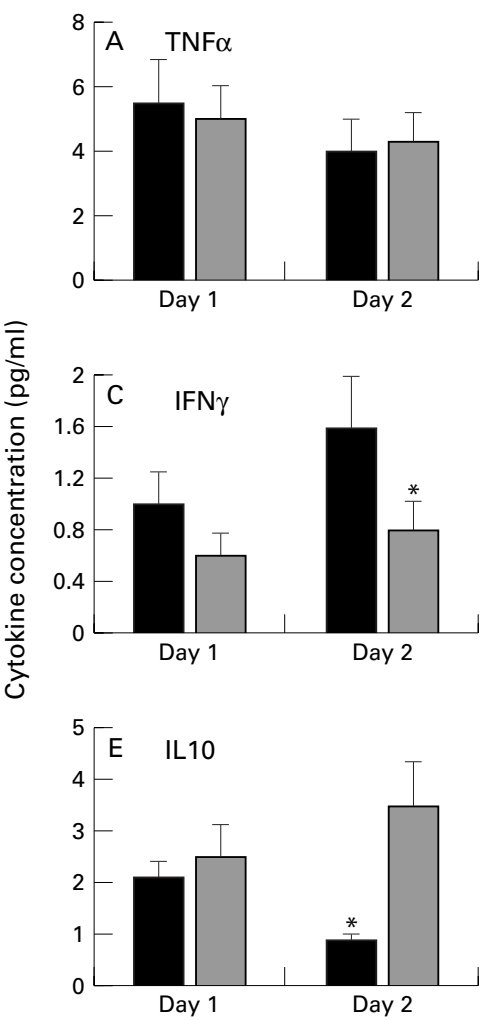

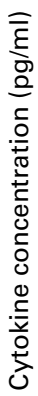
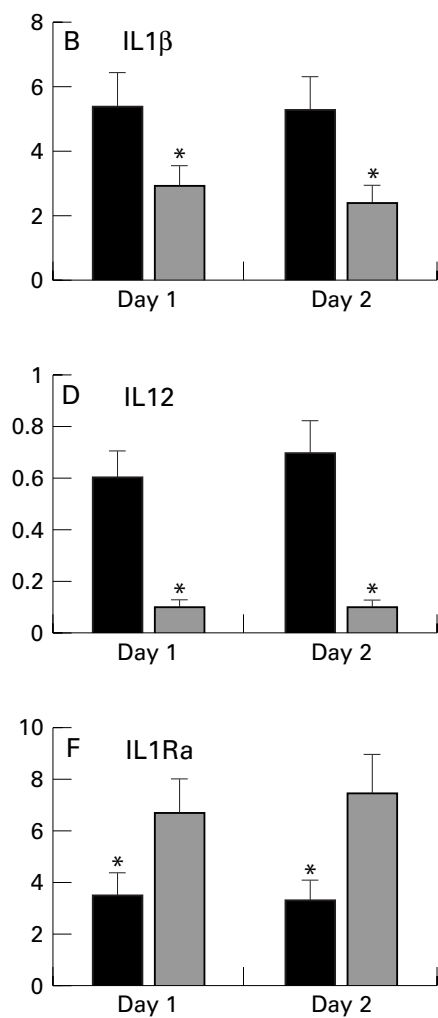

Figure 8 Effect of anti-IL12 treatment on cytokine levels in tissue-chamber model. Tissue-chambers were implanted subcutaneously seven days before injection intraperitoneally of either anti-IL12 or rat Igs. Two hours later, $100 \mu \mathrm{l} \mathrm{SCW}$ fragments were injected. At days 1 and $2200 \mu l$ tissue-chamber fluid was extracted. Levels of TNFa

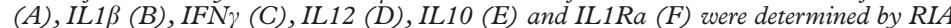
or ELISA. The data are expressed as mean (SD) cytokine level of six tissue-chambers per group. ${ }^{*} p<0.05$, Mann-Whitney U test, compared with rat Igs.
Table 2 Effect of anti-IL12 treatment on IL1Ra/IL1B and IL10/TNFa ratios

\begin{tabular}{|c|c|c|c|}
\hline \multirow{2}{*}{$\begin{array}{l}\text { Day of } \\
\text { SCW } \\
\text { arthritis }\end{array}$} & \multirow[b]{2}{*}{ Treatment } & \multicolumn{2}{|l|}{ Protein level ${ }^{\star}$} \\
\hline & & $I L 1 R a / I L 1 \beta$ & $I L 10 / T N F a$ \\
\hline Day 1 & Control (Igs) & 0.64 & 0.38 \\
\hline Day 1 & Anti-IL12 & 2.27 & 0.60 \\
\hline Day 2 & Control (Igs) & 0.60 & 0.25 \\
\hline Day 2 & Anti-IL12 & 3.55 & 0.95 \\
\hline
\end{tabular}

Cytokine ratios were calculated after treatment with either rat Igs or anti-IL12. ${ }^{\star}$ For protein ratios we used levels of cytokine found in the tisssue chamber model of inflammation (see fig 8 ).

joint swelling and chondrocyte function as treatment before induction of arthritis. No suppressive effect on joint swelling or inhibition of chondrocyte PG synthesis was observed anymore when anti-IL12 was given at day 2 .

EFFECT OF IL12 BLOCKADE DURING SCW ARTHRITIS ON CYTOKINE PATTERN

Analysis of local cytokine production at 1.5 and 4 hours after induction of arthritis showed that $\mathrm{TNF} \alpha$ levels were not changed after anti-IL12 treatment, whereas IL1 $\beta$, IL12 and IFN $\gamma$ levels were significantly reduced (fig 5A/B). Of great interest, IL10 and IL1 Ra levels were markedly increased because of IL12 elimination (fig 5C). RT-PCR analysis of synovium biopsy specimens showed that mRNA levels of TNF $\alpha$, IL1 $\beta$, IL1Ra, IL10, IL12 and IFN $\gamma$ were up regulated at days 1 and 2 of SCW induced arthritis, when compared with normal (non-inflamed) synovium (fig 6). Anti-IL12 treatment slightly decreased mRNA levels for IL1 $\beta$ and $T N F \alpha$, but marked reduction was found of mRNA levels for IFN $\gamma$, IL12 and $\mathrm{TNF} \alpha$ (figs 6,7 ). This was mainly noted at day 2 after treatment with anti-IL12. In line with cytokine levels in synovium washouts, both IL1Ra and IL10 mRNA levels were increased at day 1 and 2 of SCW arthritis after blocking endogenous IL12. When ratios of relative mRNA levels were calculated a strong shift in IL1 Ra/IL1 $\beta$ and IL10/TNF $\alpha$ balances was found (fig $6 \mathrm{G} / \mathrm{H}$ ).

NEUTRALISATION OF IL12 DURING SCW INFLAMMATION IN A TISSUE CHAMBER MODEL RESULTED IN INCREASED LEVELS OF IL10 AND IL1RA

As we cannot detect large amounts of cytokines in patella washouts at days 1 and 2 after induction of SCW, we analysed the impact of IL12 blockade on cytokine levels in a tissue chamber model. High levels $(\mathrm{ng} / \mathrm{ml})$ of various cytokines could be measured after injection of SCW fragments in a tissue chamber (fig 8). Anti-IL12 treatment of mice bearing such tissue chambers showed that neutralisation of IL12 reduced IL1 $\beta$, IFN $\gamma$ and IL12 levels, whereas $\mathrm{TNF} \alpha$ levels were not changed (fig $8 \mathrm{~B}, \mathrm{C}, \mathrm{D}, \mathrm{A})$. In line with $\mathrm{mRNA}$ and protein levels in synovial tissue, IL10 and IL1Ra levels were up regulated after anti-IL12 treatment (fig $8 \mathrm{E} / \mathrm{F}$ ). Table 2 shows that ratios of either mRNA or protein for IL1Ra/IL1 $\beta$ and IL10/ $\mathrm{TNF} \alpha$ were increased because of anti-IL12 treatment. This shows that the balance of antiinflammatory (for example, IL1Ra, IL10) and 
pro-inflammatory (for example, IL $1 \beta, \mathrm{TNF} \alpha$ ) cytokines is clearly improved after elimination of endogenous IL12, also at later time points.

\section{Discussion}

SCW arthritis is an experimental model of arthritis in which macrophages play an important part. It has been shown that bacterial cell wall fragments (peptidoglycan) induced production of IL12 by macrophages in vitro. ${ }^{29}$ Here we showed that endogenous IL12 is involved in the persistence of acute SCW induced arthritis. Suppression of joint swelling was found at days 2 and 4 and not at day 1 after intra-articular injection of SCW fragments. This shows that IL12 is not involved in joint swelling seen at the initial stage. As shown previously, $\mathrm{TNF} \alpha$ is the major cytokine regarding acute joint swelling in SCW arthritis. ${ }^{180}$ The lack of effect at day 1 is in line with the fact that shortly after onset of acute SCW arthritis TNF $\alpha$ levels were not affected by anti-IL12 treatment. Moreover, $\mathrm{TNF} \alpha$ levels were not influenced by anti-IL 12 treatment at later time points both in a tissue-chamber model of inflammation. The pivotal role of $T N F \alpha$ in the early joint swelling was corroborated by elegant studies of SCW arthritis in $\mathrm{TNF} \alpha$ deficient mice. ${ }^{31}$ The major role of $\mathrm{TNF} \alpha$ in early joint swelling was also noted in murine collagen induced arthritis. ${ }^{25}{ }^{32}$ The suppressive effect of anti-IL12 on joint swelling in sub-acute stages of arthritis could be explained on the one hand by the reduced levels of IFN $\gamma$, IFN $\gamma$ itself being involved in joint swelling and on the other hand reduction of NO. ${ }^{33}$ In respect to joint swelling, endogenous IL12 is involved between 24-48 hours after onset of SCW arthritis, but seems again less dominant at later stages, as anti-IL12 treatment started at day 2 was ineffective.

Inhibition of chondrocyte PG synthesis in the arthritic cartilage is a common feature seen in experimental arthritis models and IL1 is the pivotal cytokine in this inhibition. ${ }^{34}$ In this study it was shown that elimination of IL12 during onset results in restoration of chondrocyte function at days 2 and 4 of acute SCW arthritis. IL1 $\beta$ levels were reduced by anti-IL12 treatment, but significant levels were still found in synovial tissue washouts. At days 1 and 2 reduction of IL1 activity was also observed in tissue chamber fluid after IL1 2 blockade. This was in line with findings in tumour bearing mice treated with anti-IL12 antibodies in which decreased IL1 $\beta$ levels were reported. ${ }^{35}$ Recently, it was demonstrated that chondrocyte PG synthesis induced by IL1 was mediated by $\mathrm{NO}$ as $\mathrm{NOS}_{2}$ deficient mice were shown to be resistant for IL1 induced chondrocyte PG synthesis. ${ }^{36}{ }^{37}$ Cytokine induced NO synthesis by macrophages, synoviocytes and chondrocytes is strongly increased by IFN $\gamma .^{38} 39$ IL12 is a potent inducer of IFN $\gamma$ production and we showed that anti-IL12 treatment resulted in markedly decreased IFN $\gamma$ levels in the synovial tissue washouts. Furthermore, synergistic effects on inhibition of chondrocyte PG synthesis between IL1 and several other cytokines, such as $\mathrm{TNF} \alpha, \mathrm{IFN} \gamma$ were demonstrated. ${ }^{40}$ Recently, it was demonstrated that there is a direct role of IL12 in NO production. ${ }^{41}$ Although we could not measure $\mathrm{NO}$ in the one hour culture supernatants, it seems probable that NO production is decreased by anti-IL12 treatment as local mRNA level of iNOS was reduced at day 1 and 2 (data not shown). The combination of IL1 suppression, IFN $\gamma$ reduction and direct decrement of NO is probably responsible for the reduced the inhibition of chondrocyte PG synthesis.

Blockade of IL1 activity by application of IL1Ra completely prevents inhibition of chondrocyte PG synthesis during acute SCW arthritis as described previously. ${ }^{18}$ Apart from reduction of the cytokines IL1, IFN $\gamma$ and NO the restoration of chondrocyte PG synthesis could be the result of enhancement of IL1Ra and IL10 levels by anti-IL12. IL12 exposure to mononuclear cells reduced the IL1Ra production by these cells in vitro. ${ }^{42}$ Administration of IL10 during acute SCW arthritis was shown to increase chondrocyte function whereas antiIL10 aggravated inhibition of PG synthesis at days 2 and 4 after injection of SCW. ${ }^{19}$ IL10 is an inhibitor of IL1 and NO production and it up regulates IL1Ra production in several cell types. Reduction of IL $1 \beta$, IL12 and IFN $\gamma$ by IL12 blockade was not only found shortly after onset of acute SCW arthritis, but also at later stages (days 1 and 2). The latter was examined in a tissue-chamber model of inflammation. As shown previously, high levels of several cytokines could be detected in the fluid that can be easily isolated from the chamber. ${ }^{22}$ We found some differential effect of IL12 in synovium and tissue chambers. This could be attributable to the fact that synovial cytokine levels were measured during onset, and in tissue chambers cytokines were determined in established SCW inflammation.

Histological examination showed that neutralisation of IL12 reduced the number of inflammatory cells in joint tissues. Recently, it has been reported that overexpression of IL12 with an adenoviral vector leads to upregulation of proinflammatory chemokines, including MIP-1 $\alpha$, MIP-2 and MCP- $1 .^{43}$ These chemoines direct leucocyte migration into inflamed tissue and blockade of IL12 may lead to decreased expression. Furthermore, it was shown that IL10 down regulated ICAM expression and anti-IL10 treatment of collagen induced arthritis increased expression of MIP- $1 \alpha$ and MIP-2. ${ }^{44}$ Therefore, the reduced number of inflammatory cells in the joint might also be explained by markedly increased IL10 and decreased IL12 levels in the anti-IL12 treated animals. Finally, IL1 itself induces production of pro-inflammatory chemokines and expression of adhesion molecules. ${ }^{46}$ A shift in the balance of IL1Ra/ IL1 $\beta$ was noted after IL1 2 elimination, and this may also contribute to reduce cell influx.

Recently, three pathways of IL 12 production by either macrophages or dendritic cells have been described. ${ }^{47}$ Direct stimulation by bacterial agents, triggering by $\mathrm{T}$ cell dependent immune responses and activation by the matrix glycosaminoglycan hyaluran. ${ }^{48}$ The latter is mediated by binding of low molecular 
fragments of matrix proteoglycans to adhesion surface molecule CD44 and these PG fragments are abundantly present in an inflamed joint. As IL12 promotes Th1 responses, it may be possible that IL12 generates a local immune response in the joint towards cartilage autoantigens like CII, gp-39 and aggrecan. ${ }^{49}$ In other models of autoimmune inflammation such as collagen induced arthritis, experimental colitis, diabetes in non-obese diabetic mice and experimental allergic encephalomyelitis, an essential role of IL12 was observed..$^{280-52}$ Elimination of IL12 in these animal models by anti-IL12 treatment leads to suppression or prevention of disease expression. We recently found that intra-articular IL12 gene transfer with an adenoviral vector aggravates acute SCW arthritis and local IL12 expression can promote conversion of an acute SCW arthritis to a chronic destructive arthritic process (manuscript in preparation). This suggests that IL12 not only plays a part in the onset of arthritis but could also determine the chronicity of the disease. Whether generation of joint specific Th1 response occurred in these animals is still under investigation. This study shows that IL12 is a primary pro-inflammatory cytokine during onset of bacterial induced arthritis and blockade of IL12 ameliorates joint swelling, leads to restoration of chondrocyte function, and reduces influx of leucocytes. Anti-IL12 treatment could be efficacious in the treatment of patients with arthritis. Funding: this research was supported by European Union
(BIOMED-2 program, BMH4-CT96-1698) and The Catholic Rheumatism Foundation, Nijmegen, the Netherlands.

1 Stern AS, Podlaski FJ, Hulmes JD, Pan EY, Quinn PM, Wolitzki AG, et al. Purification of homogeneity and partial characterization of cytotoxic lymphocyte maturation factor from human B-lymphoblastoid cells. Proc Natl Acad Sci USA 1990;87:6808-12.

2 Kobayashi M, Fitz L, Ryan M, Hewick SC, Clark SC, Chan $\mathrm{SH}$, et al. Identification and purification of natural killer cell stimulatory factor (NKSF), a cytokine with multiple cell stimulatory factor (NKSF), a cytokine with multiple
biologic effects on human lymphocytes. J Exp Med 1989;170:827-45.

3 D'Andrea A, Rengaraju M, Valiante NM, Chehimi J, Kubin $\mathrm{M}$, Aste $\mathrm{M}$, et al. Production of natural killer cell stimulatory factor (interleukin-12) by peripheral blood mononuclear cells. J Exp Med 1992;176:1387-98.

4 Gazzinelli RT, Hieny S, Wynn TA, Wolf SF, Sher A. IL-12 is required for the T-lymphocyte-independent induction of interferon-gamma by an intracellular parasite and induce resistance in T-cell-deficient hosts. Proc Natl Acad Sci USA 1993;90:6115-19.

5 Seder RA, Gazzinelli RT, Sher A, Paul WE. Interleukin-12 acts directly on $\mathrm{CD} 4^{+}$T-cells to enhance priming for interferon- $\gamma$ production and diminished interleukin- 4 inhibition of such priming. Proc Natl Acad Sci USA 1993;90: 10188-92.

6 Abbas AK, Murphy K M, Sher A. Functional diversity of helper T lymphocytes. Nature 1996;383:787-93.

7 Wysocka M, Kubin M, Vieira LQ, Ozmen L, Garotta G, Wysocka $M$, Kubin $M$, Vieira $L Q$, Ozmen $L$, Garotta $G$,
Scott $P$, et al. Interleukin-12 is required for interferon- $\gamma$ Scott $\mathrm{P}$, et al. Interleukin-12 is required for interferon- $\gamma$
production and lethality in lipopolysaccharide-induced production and lethality in lipopolysacchar
shock in mice. Eur J Immunol 1995;25:672-6.

8 Ozmen L, Pericin M, Hakimi J, Chizzonite RA, Wysocka M, Trinchieri G, et al. Interleukin-12, interferon gamma and tumor necrosis factor alpha are the key cytokines of the generalized Shwartzman reaction. J Exp Med 1994;180 907-15.

9 Trinchieri G. IL-12: a proinflammatory cytokine with immunoregulatory functions that bridges innate resistance and antigen specific adaptive immunity. Annu Rev Immunol 1995; 13:251-76.

10 Mattner F, Magram J, Ferrante J, Launois P, Di Padova K, Behin R, et al. Genetically resistant mice lacking interleukin-12 are susceptible to infection with Leishmania major and mount a polarized Th2 cell response. Eur J Immunol 1996;26:1553-9.

11 Magram J, Connaughton SE, Warrier RR, Carvajal DM, Wu C-Y, Ferrante J, et al. IL-12 deficient mice are defective in IFN- $\gamma$ production and type I cytokine responses. Immuin IFN- $\gamma$ production

12 Segal BM, Shevach EM. IL-12 unmasks autoimmune disease in resistance mice. J Exp Med 1996;184:771-5.
13 Chen E, Keystone EC, Fish EN. Restricted cytokine expression in rheumatoid arthritis. Arthritis Rheum 1993;36: 901-10.

14 Morita Y, Yamamura M, Nishida K, Harada S, Okamoto H, Inoue $\mathrm{M}$, et al. Expression of interleukin-12 in synovial tissue from patients with rheumatoid arthritis. Arthritis Rheum 1998;41:306-14 15 Cromartie WJ, Craddock JG, Schwab JH, Anderle SK, Yang
C. Arthritis in rats after systemic injection of streptococcal cells or cell wall. J Exp Med 1977;146:1585-602.

16 Schrier DJ, Schimmer RC, Flory DM, Tung DK, Ward PA. Role of chemokines and cytokines in a reactivation model of arthrtis induced by injection with streptococcal cell walls. J Leukoc Biol 1998;63:359-63.

17 Van den Broek MF, van den Berg WB, van de Putte LBA, Severijnen AJ. Streptococcal cell wall induced arthritis and flare-up reactions in mice induced by homologous and heterologous cell walls. Am J Pathol 1988;133:139-49.

18 Kuiper S, Joosten LAB, Bendele AM, Edwards III CK, Arntz OJ, Helsen MMA, et al. Different roles tumour necrosis factor $\alpha$ and interleukin-1 in murine streptococcal cell wall arthritis. Cytokine 1998;10:690-702.

19 Lubberts E, Joosten LAB, Helsen MMA, van den Berg WB. Regulatory role of interleukin 10 in joint inflammation and cartilage destruction in murine streptococcal cell wall (SCW) arthritis. More therapeutic benefith combination therapy than

20 Matthys P, Vermeire K, Mitera T, Heremans H, Huang S, Billiau A. Anti-IL-12 antibody prevents the development and progression of collagen-induced arthritis in IFN- $\gamma$
receptor-deficient mice. Eur J Immunol 1998;28:2143-51.

21 Kruijsen MWM, van den Berg WB, van den Putte LBA, van den Broek WJM. Detection of and quantification of experimental joint inflammation in mice by measurements of
${ }_{99 \mathrm{~m}}$ Tc-pertechnetate uptake. Agents Actions 1981;11: 640-2.

22 Oluyomi AO, Nguyen H, Towbin H, Dawson J, Vosbeck K. Differential effects of prednisolone and indomethacin on zymosan-induced inflammation in a modified murine tissue-chamber model. Inflamm Res 1995;44:350-6.

23 Drenth JPH, van Uum SMH, van Deuren M, Pesman GJ, van der Ven-Jongekrijg J, van de Meer JWM. Endurance run increases circulating IL- 6 and IL-1Ra but down reguates ex vivo TNF $\alpha$ and IL-1 $\beta$ production. J Appl Physiol 1995;79:1497-503.

24 Van Meurs JBJ, van Lent PLEM, Joosten LAB, van der Kraan PM, van den Berg WB. Quantification of mRNA levels in joint capsule and articular cartilage in the murine knee joint by RT-PCR. Rheumatol Int 1997;16:197-205.

25 Joosten LAB, Helsen MMA, van de Loo FAJ, van den Berg WB. Anti-cytokine treatment of established collagen type II arthritis in DBA/ 1 mice: A comparative study using anti-TNF $\alpha$, anti-IL- $1 \alpha / \beta$ and IL-1ra. Arthritis Rheum 1996;39:797-809.

26 Chomczynski P, Sacchi N. Single step method of RNA isolation by acid guanidinium thiocyanate-phenol-chloroform extraction. Anal Biochem 1987;162:156-9.

27 Kanangat S, Blair P, Reddy R, Deheshia M, Godfrey V, Rose BT, et al. Disease in the scurfy (sf) mouse is associated with overexpression of cytokines genes. Eur J Immunol 1996;26: 161-7.

28 Joosten LAB, Lubberts E, Helsen MMA, van den Berg WB. Dual role of interleukin-12 in early and late stages of murine collagen type II arthritis. J Immunol 1997;159: 4094-102.

29 Lawrence C, Nauciel C. Production of interleukin-12 by murine macrophages in response to bacterial peptidoglycan. Infect Immun 1998;66:4947-9.

30 Van den Berg WB, Joosten LAB, Helsen MMA, van Lent PLEM, van de Loo FAJ. Cytokine profile dependent on the type of arthritis: dominant role of IL-1 in cartilage destruction. Arthritis Rheum 1994;37:S279.

31 Van den Berg WB, Kollias G, Joosten LAB, van de Loo FAJ. Relative role of IL-1 and TNF in SCW arthritis: studies in IL-1 $\beta$ and TNF $\alpha$ knockout mice. Arthritis Rheum 1998;41:S1908.

32 Williams RO, Feldmann M, Maini RN. Anti-TNF ameliorates joint disease in murine collagen-induced arthritis. Proc Natl Acad Sci USA 1992;89:9784-8.

33 Boissier M-C, Chiocchia G, Bessis N, Hajnal J, Garotta G, Nicoletti $\mathrm{F}$, et al. Biphasic effect of interferon- $\gamma$ in murine collagen-induced arthritis. Eur J Immunol 1995;25:118490 .

34 Van de Loo FAJ, Joosten LAB, van Lent PLEM, Arntz OJ, van den Berg WB. Role of interleukin-1, tumor necrosis factor I, and interleukin-6 in cartilage proteoglycan metabolism and destruction. Arthritis Rheum 1995;38: 164-72.

35 Lakshmi Rao K, Varalakshmi CH, Mubarak Ali A, Khar A. Administration of anti-IL-12 antibody in vivo inhibits rejection of a rat histocytoma and suppresses cytokine response in a tumour-bearing host. Immunology 1997;92: $381-7$.

36 Taskiran D, Stefanovic-Racic M, Georgescu H, Evans C. Nitric oxide mediates suppression of cartilage proteoglycan synthesis by interleukin-1. Biochem Biophys Res Commun 1994;200:142-8.

37 Van de Loo FAJ, Arntz OJ, van Enckevort FHJ, van Lent PLEM, van den Berg WB. Reduced cartilage proteoglycan loss during zymosan-induced gonarthritis in NOS2 deficient mice and in anti-interleukin-1 treated wild-type mice with unabated joint inflammation. Arthritis Rheum 1998; 41:634-6. 
38 Palmer RMJ, Hickery MS, Charles IG, Moncade S, Bayliss MT. Induction of nitric oxide synthase in human chondro-

39 Sakurai H, Kohsaka H, Liu MF, Higashiyama H, Hirata Y, Kanno K, et al. Nitric oxide production and inducible nitric oxide synthase expression in inflammatory arthritis. J Clin Invest 1995;96:2357-63.

40 Dodge GR, Diaz A, Sanz-Rodrigues C, Reginato AM, Jimenez SA. Effects of interferron- $\gamma$ and tumor necrosis factor $\alpha$ on the expression of the genes encoding aggrecan, biglycan and decorin core proteins in cultured human chondrocytes. Arthritis Rheum 1998;41:274-83.

41 Huang F-P, Feng G-J, Lindop G, Stott DI, Liew FY. The role of interleukin-12 and nitric oxide in the development of spontaneous autoimmune disease in MRL-MR-lpr/lp mice. J Clin Invest 1996;183:1447-59.

42 Seitz M, Loetscher P, Dewald B, Towbin H, Baggiolini M. Opposite effects of interleukin-13 and interleukin-12 on the release of inflammatory cytokines, cytokine inhibitors and prostaglandin $\mathrm{E}$ from synovial fibroblasts and blood mononuclear cells. Eur J Immunol 1996;26:2198-202

43 Parks E, Strieter RM, Lukacs NW, Gauldie J, Hitt M, Graham FL, et al. Transient gene transfer of IL-12 regulates chemokine expression and disease severity in experimental arthritis. J Immunol 1998;160:4615-19.

44 Walmsley M, Katsikis PD, Abney M, Katsikis E, Parry S, Williams RO, et al. Interleukin-10 inhibition of the progression of established collagen-induced arthritis. $\mathrm{Ar}-$ thritis Rheum 1996;39:495-503.
45 Willems F, Marchant A, Delwille JP, Gerard C, Delvaux A, Velu $\mathrm{T}$, et al. Interleukin-10 inhibits B7 and intercellular adhesion molucule-1 expression on human monocytes. Eur J Immunol 1994;24:1007-9.

46 Arend WP, Dayer J-M. Inhibition of the production and effects of interleukin-1 and tumor necrosis factor $\alpha$ in rheumatoid arthritis. Arthritis Rheum 1995;38:151-60.

47 Trinchieri G. Immunobiology of interleukin-12. Immunol Res 1998;17:269-78.

48 Hodge-Dufour J, Noble PW, Horton MR, Bao C, Wysoka $\mathrm{M}$, Burdick MD, et al. Induction of IL-12 and chemokines by hyaluronan requires adhesion-dependent priming of resistant but not elicited macrophages. J Immunol 1997; 159:2492-500.

49 Cope AP, Sønderstrup G. Evaluating candidate autoantigens in rheumatoid arthritis. Spinger Semin Immunopathol 1998;20:23-39.

50 Neurath MF, Fuss I, Kelsall BL, Struber E, Strober W. Antibodies to interleukin-12 abrogate established experimental colitis in mice. J Exp Med 1995;182:1281-90.

51 Trembleau S, Penna G, Bosi E, Mortara A, Gately MK, Adorini L. Interleukin-12 administration induces T helper type I cells and accelerates autoimmune diabetes in NOD mice. J Exp Med 1995;181:817-21.

52 Leonard JP, Waldburger KE, Goldman SJ. Prevention of experimental autoimmune encephalomyelitis by antibodies against interleukin-12. J Exp Med 1995;181:381-6. 